\title{
Profil Kesalahan Siswa dalam Menyelesaikan Soal Getaran dan Gelombang Berbasis HOTS (Higher Order Thinking Skill)
}

\author{
Fitrianing Ekawati $^{1}$, Jeffry Handhika ${ }^{2}$, Farida Huriawati ${ }^{3}$ \\ ${ }^{1)}$ Mahasiswa Program Studi Pendidikan Fisika, Universitas PGRI Madiun \\ ${ }^{2,3)}$ Dosen Program Studi Pendidikan Fisika, Universitas PGRI Madiun \\ e-mail: ${ }^{1)}$ Fitrianing45@gmail.com; ${ }^{2}$ jhandhika@unipma.ac.id; ${ }^{3)}$ Frd21pfisae@gmail.com
}

\begin{abstract}
Abstrak: Penelitian yang dilakukan bertujuan untuk mengidentifikasi kesalahan-kesalahan yang dilakukan siswa dalam menyelesaikan soal-soal fisika pada materi getaran dan gelombang. Penelitian yang dilakukan menggunakan metode deskriptif kualitatif. Penelitian dilaksanakan SMPN 2 Geger. Subyek penelitian yang dipilih adalah siswa kelas VIII A. Analisis data dilakukan terhadap 26 siswa. Teknik pengumpulan data dengan metode observasi dan metode tes. Validasi data dilakukan dengan triagulasi data yaitu membandingkan data hasil observasi dan data hasil tes. Analisis data dilakukan melalui tahap reduksi data, penyajian data, dan penarikan kesimpulan. Berdasarkan analisis data dan pembahasan diperoleh kesimpulan: kesalahan dalam memahami konsep dan kesalahan interpretasi, siswa tidak dapat memahami simbol yang digunakan dalam menjawab soal.
\end{abstract}

Kata Kunci: Profil, Kesalahan Menyelesaikan Soal, Getaran dan Gelombang, HOTS

\section{PENDAHULUAN}

Tujuan tes yang paling penting untuk mengetahui tingkat kemampuan siswa, juga dapat digunakan untuk mengasah kemampuan berpikir tingkat tinggi siswa. Soal-soal yang digunakan dapat berisi pertanyaan yang menguji siswa dalam hal pemecahan masalah, berpikir kritis dan berpikir kreatif. Menyusun tes yang mempunyai bobot kemampuan berpikir tinggi bukanlah hal mudah. Sehingga seringkali instrumen yang digunakan di sekolah sekolah hanya mengukur aspek ingatan sehingga kurang dapat melatih kemampuan berpikir tingkat tinggi. Penulisan soal yang menuntut kemampuan berpikir tingkat tinggi menjadi tugas pihak guru dalam kegiatan penilaian.

Istiyono, dkk (2014) melakukan penelitian untuk mengembangkan instrumen keterampilan berpikir tingkat tinggi fisika (PhysTHOTS) peserta didik SMA. Karakteristik PhysTHOTS dan instrumen HOTS yang dikembangkan memenuhi syarat digunakan untuk mengukur keterampilan berpikir tingkat tinggi peserta didik SMA. PhysTHOTS berbentuk pilihan ganda dan memiliki kelemahan yaitu: penetapan subyek hanya untuk siswa SMA dan kemungkinan peserta didik untuk melakukan tebakan jawaban masih cukup besar. Penelitian HOTS kebanyakan mengambil subyek siswa SMA, padahal kemampuan berpikir tingkat tinggi harusnya dimulai sedini mungkin.

Getaran merupakan salah satu materi fisika yang dipelajari oleh siswa kelas VIII SMP. Siswa dalam mempelajari materi getaran masih sering melakukan kesalahan dalam mengerjakan soal-soal yang diberikan, sehingga ditemukan permasalahan-permasalahan yang perlu dianalis. Berdasarkan beberapa penelitian mengenai analisis kesalahan siswa dalam menyelesaikan soal begitu penting, sehingga perlu dilakukan penelitian yang lebih lanjut. Melalui penelitian yang dilakukan, diharapkan kesalahan-kesalahan yang terjadi dapat diminimalisir dengan memberikan perlakuan atau tindakan untuk mengantisipasi munculnya penyebab kesalahan terjadi kembali. Dengan demikian, diharapkan dapat meningkatkan hasil belajar fisika pada siswa. 
Berdasarkan hasil observasi ketika melaksanakan praktik pengalaman lapangan (PPL) di SMPN 2 Geger, ternyata diketahui beberapa siswa masih melakukan kesalahan dalam menyelesaikan soal fisika. Walaupun soal sudah diberikan guru saat latihan soal dalam pembelajaran di kelas, siswa masih ada yang melakukan kesalahan dalam menyelesaikan soal ketika diberikan tes. Dalam pembelajaran fisika kelas XI IPA, materi getaran dan gelombang merupakan materi yang cukup sulit untuk dipahami. Berdasarkan wawancara dengan guru mata pelajaran fisika di SMPN 2 Geger, masih banyak dijumpai kesalahan yang dilakukan oleh siswa. Nilai yang didapatkan siswa pun cukup rendah, masih dibawah nilai KKM. Faktor yang menyebabkan kesalahan tersebut beraneka ragam. Beberapa kesalahan berpengaruh terhadap pembelajaran fisika disekolah, baik secara langsung maupun tidak langsung. Kesalahan merupakan hal yang wajar dilakukan siswa pada saat belajar,. Akan tetapi, kesalahan-kesalahnyang muncul seharusnya dapat diminimalisir.

\section{METODE PENELITIAN}

Penelitian ini dilakukan pada siswa kelas VIII A SMPN 2 Geger pada tahun ajaran 2016/2017. Jenis penelitian yang digunakan adalah penelitian deskriptif kualitatif. Metode pengumpulan data dalam penelitian ini menggunakan teknik observasi dan tes. Metode tes merupakan metode utama yang digunakan dalam pengumpulan data pada penelitian ini., sedangkan observasi merupakan metode bantu sebagai pelengkap yang hasilnya digunakan sebagai pembanding dalam proses triagulasi data. Tes dan observasi dilakukan pada siswa kelas VIII A. Analisis data dilakukan dengan cara reduksi data, penyajian data, dan penarikan kesimpulan.

\section{HASIL DAN PEMBAHASAN}

Setelah dilakukan analisis terhadap lembar jawab siswa hasil tes tertulis materi getaran dan gelombang, dapat diketahui kesalahan-kesalahan yang dilakukan siswa dalam menyelesaikan soal fisika materi getaran dan gelombang. Kesalahan disajikan dalam persentase banyaknya siswa yang menjawab salah dari setiap indikator yang ada. Terdapat 14 kriteria kemampuan berpikir tingkat tinggi yang terdiri dari tiga indikator yaitu berpikir kritis, berpikir kreatif dan pemecah masalah. Kriteria 1 merevisi konsep yang salah. Kriteria 2 mampu membuat keputusan. Kriteria 3 memformulasikan persamaan. Kriteria 4 menyatakan hubungan sebab dan akibat. Kriteria 5 berani eksperimen. Kriteria 6 menghasilkan sesuatu yang baru. Kriteria 7 bekerja secara teliti. Kriteria 8 mengorganisasi konsep. Kriteria 9 merencanakan strategi. Kriteria 10 mengevaluasi keputusan. Kriteria 11 berani spekulasi. Kriteria 12 mengorganisasi konsep. Kriteria 13 menerapkan konsep yang sesuai masalah. Kriteria 14 mengubah persamaan. Persentase Kesalahan yang dilakukan siswa berdasarkan banyaknya siswa yang menjawab benar dan salah setiap soal tersaji dalam histogram berikut: 


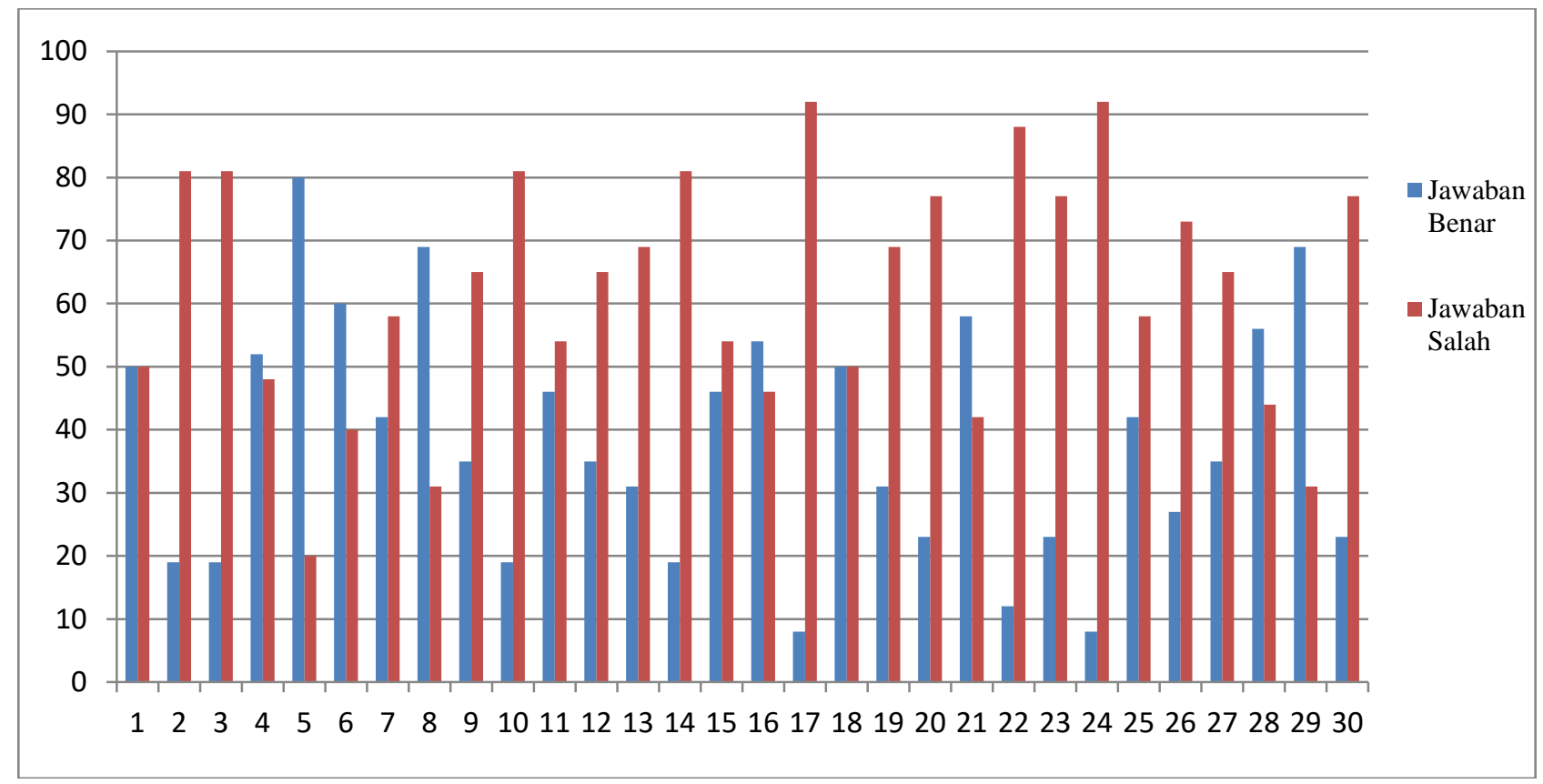

Berdasarkan histogram tersebut tedapat tiga kelompok siswa yaitu siswa dengan prosentase jawaban salah dan benar seimbang, presentase siswa menjawab benar lebih banyak dan presentase siswa menjawab salah lebih banyak. Siswa dengan presentase menjawab benar dan salah seimbang terdapat pada soal no 1 dan soal no 18 .

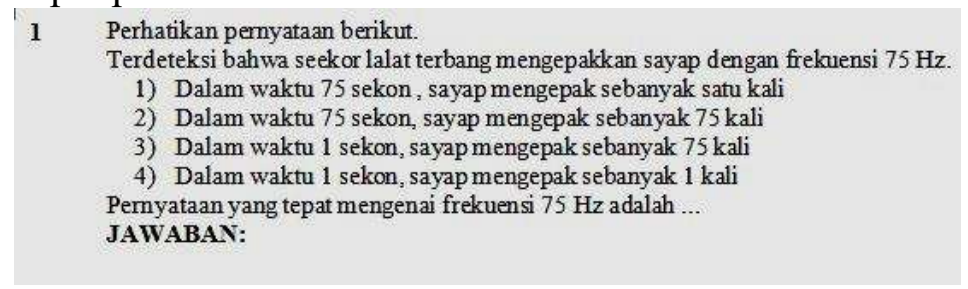

Gambar 1. Soal No 1

18 Sebuah "transmitter" mengirimkan burri ke sekumpulan ikan dilaut untuk mengetahui letak ikan tersebat. Waktu yang dibutuhkan burvi 0.5 sekon untuk kembali lagike titik awal pengiriman (transmitter). Jika kectpatan buryi di air laut $1200 \mathrm{~m} / \mathrm{s}$, maka jarak ikan dan transmitter sejauh. JAWABAY:

\section{Gambar 2. Soal No 18}

Berdasarkan kriterianya soal tersebut merupakan kriteria soal dalam indikator berpikir kritis. Presentase siswa pada soal no 1 menjawab benar 50\% dan siswa menjawab salah 50\%. Presentase siswa pada soal no 18 juga sama yaitu 50\% menjawab benar dan $50 \%$ untuk menjawab salah.

Siswa dengan presentase menjawab benar lebih banyak terdapat pada soal no 5 , soal no 8 , dan soal no 29. 


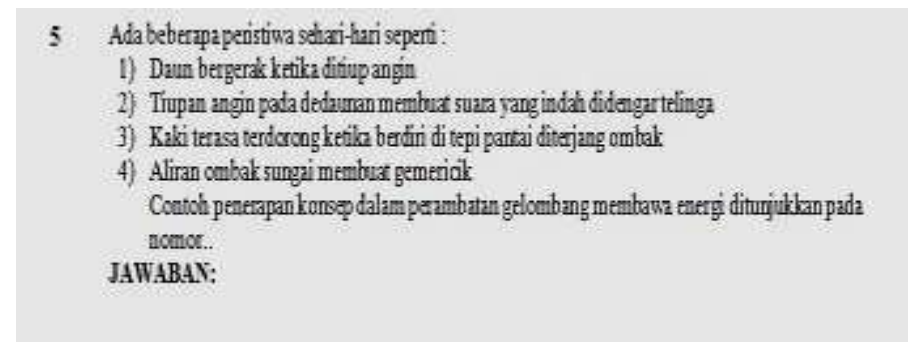

\section{Gambar 3. Soal No 5}

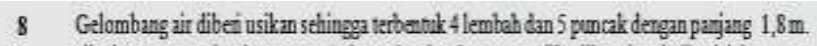

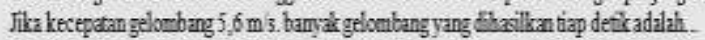
JAWABAY:

Gambar 4. Soal No 8

29 Perbatikan beberapakejatan berikut

1) Menentukan kecepetan aliran air

2) Menentukankedalaman laur

3) Meagiancukan batu ginjal

4) Memperbaiki gangguan pengithatan

Kegiatan yang memanfastkan gelombang buryi dinari ukan oleh angka. JAWABAN:

Gambar 5. Soal No 29

Berdasarkan kriterianya soal tersebut merupakan soal dalam indikator berpikir kritis. Soal no 5 termasuk dalam indikator berpikir kritis. Presentase siswa menjawab benar $80 \%$ dan $20 \%$ untuk menjawab salah. Soal no 8 merupakan soal dalam indikator berpikir kreatif. Presentase siswa menjawab benar 69\% dan untuk menjawab salah 39\%. Soal no 29 termasuk dalam indikator pemecah masalah. Presentase siswa menjawab benar 69\% dan yang menjawab salah $39 \%$.

Siswa dengan presentase menjawab salah lebih banyak terdapat pada soal no 17 , soal no 22 , dan soal no 24.

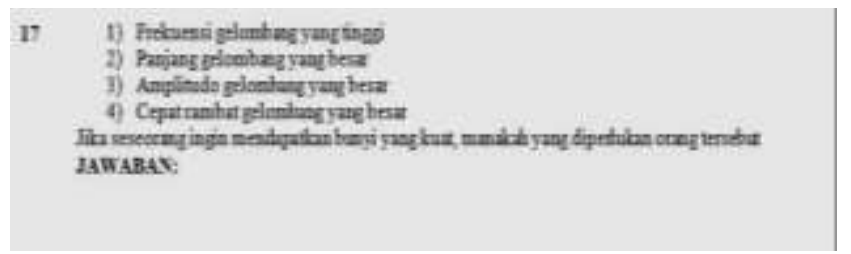

Gambar 6. Soal No 17

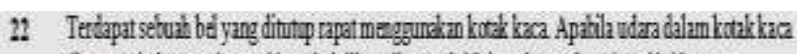

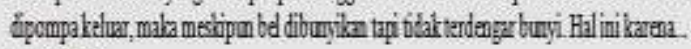
JAWABAX

Gambar 7. Soal No 22

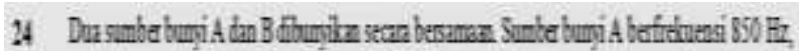

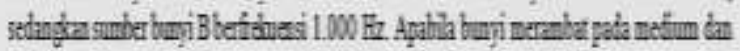

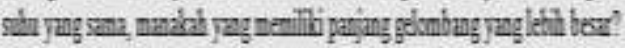

Gambar 8. Soal No 24 
Berdasarkan kriterianya soal 17 merupakan kriteria soal dalam indikator berpikir kreatif. Presentase siswa yang menjawab soal dengan benar hanya $8 \%$ dan siswa yang menjawab salah sebesar 92\%. Sedangkan soal no. 22 dan 24 merupakan soal dengan indikator pemecah masalah. Presentase siswa pada soal no 22 menjawab benar $12 \%$ dan menjawab salah $88 \%$. Presentase siswa pada soal no 24 menjawab benar 8\% dan salah sebesar 92\%. Sehingga berdasarkan jawaban benar dan salah siswa, soal dengan indikator berpikir kritis lebih mudah bagi siswa dibandingkan soal dengan indikator berpikir kreatif dan pemecah masalah.

Berdasarkan hasil jawaban siswa pada lembar jawab, dapat diketahui kesalahan yang dilakukan siswa dalam menyelesaikan soal pada materi getaran dan gelombang. Kesalahan Konsep yaitu Siswa salah dalam memahami konsep pada soal dan beberapa pernyataan yang disediakan. Siswa sudah dapat dapat memahami soal, tetapi belum menangkap informasi/konsep yang terkandung dalam soal secara tepat sehingga tidak dapat memproses lebih lanjut solusi dari permasalahan soal. Seperti yang terdapat dalam gambar 9 .

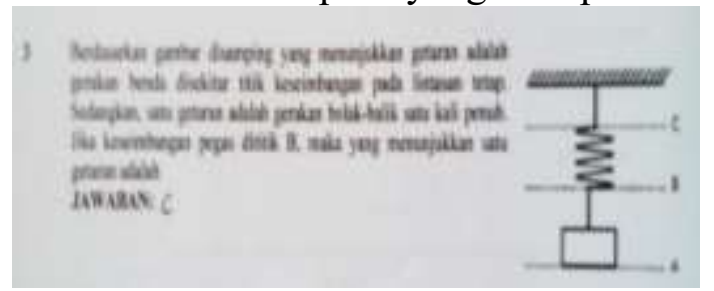

Gambar 9. Siswa hanya asal menjawab

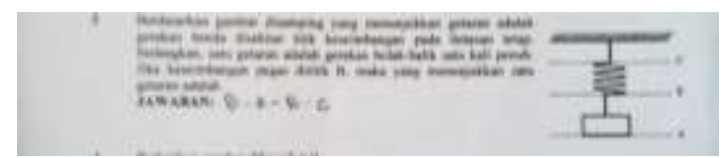

Gambar 10. Siswa kurang paham

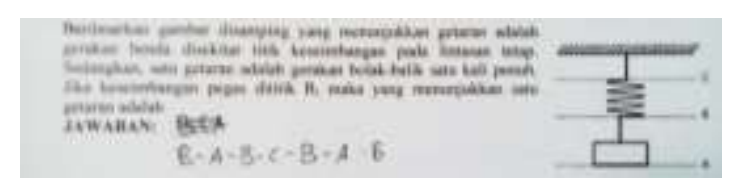

Gambar 11. Siswa menjawab benar

Kesalahan interpretasi yaitu Siswa tidak dapat memahami data-data yang ada pada soal. Siswa tidak memahami simbol-simbol yang digunakan pada soal. Pada soal ini siswa dapat menjawab dengan benar tetapi tidak dapat menggunakan simbol-simbol dalam fisika. Seperti yang terdapat dalam gambar berikut:

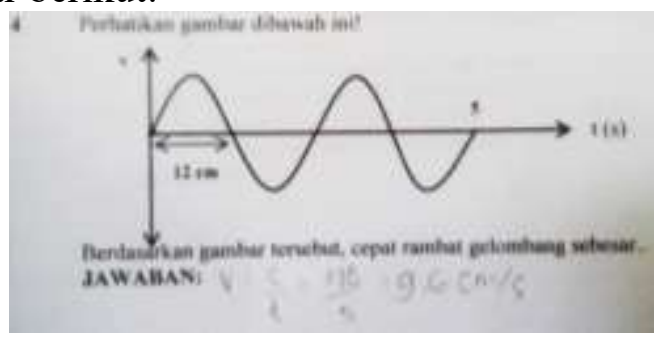

Gambar 12. Kesalahan interpretasi 


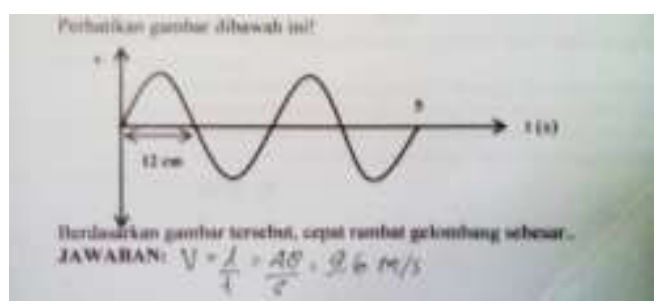

Gambar 13. Kesalahan interpretasi

Siswa sering salah strategi berupa ketidaktahuan siswa dalam memilih prosedur/langkahlangkah yang tepat untuk menyelesaikan soal-soal yang disediakan sehingga siswa hanya asal menjawab.

Siswa salah dalam penerapan rumus berupa kesalahan kesalahan menggunakan perumusan konsep, prinsip, teori dan hukum untuk melakukan perhitungan.

Siswa salah dalam perhitungan berupa kesalahan melakukan perhitungan dalam bentuk persamaan yang berlaku. Siswa kurang teliti atau terburu-buru dalam melakukan perhitungan untuk menyelesaikan soal.

\section{KESIMPULAN}

Berdasarkan pada hasil penelitian dan pembahasan dapat disimpulkan bahwa siswa lebih mudah mengerjakan soal dengan indikator soal berpikir kritis.jenis kesalahan yang dilakukan oleh siswa dalam menyelesaikan soal getaran dan gelombang yaitu: kesalahan dalam memahami konsep dan kesalahan interpretasi, siswa tidak dapat memahami simbol yang digunakan dalam menjawab soal.

\section{UCAPAN TERIMAKASIH}

Penulis mengucapkan terimaksih kepada semua pihak yang telah mendukung penyelesaian artikel ini diantaranya kepada bapak Jeffry Handhika, selaku Kaprodi pendidikan Fisika. Ibu Farida Huriawati, selaku Dosen Pendidikan Fisika yang telah meluangkan waktunya. Bapak Idham Kholid, selaku kepala Sekolah SMPN 2 Geger. Ibu Sulastri, selaku guru mata pelajaran Fisika yang telah bersedia memberikan waktu untuk dilakukannya penelitian ini.

\section{DAFTAR PUSTAKA}

Istiyono, E., Mardapi, D., Suparno. 2014. Pengembangan Tes Kemampuan Berpikir Tingkat Tinggi Fisika (PysTHOTS) Peserta Didik SMA. (Online),(http://journal.uny.ac.id/indek.php/jpep/article/viewfile/2120/1765, diunduh 10 Maret 2017). 